\title{
DSTENSIVE MYELOID RESPONSE DURING FOLIC ACID THERAPY IN MEGALOBLASTIC ANAEMIA OF PREGNANCY
}

\author{
BY \\ GRACE M. RITCHIE \\ From the Department of Pathology, Stobhill and Western District Hospitals, Glasgow
}

(RECEIVED FOR PUbliCATION MAY 3, 1952)

Numerous examples of leukaemoid pictures occurring in a variety of conditions have been described in the literature, but I have been unable to trace any case similar to that about to be described.

\section{Case Report}

The patient, aged 29 years, para 3, unmarried, and of subnormal intelligence, was first seen in the thirtyfourth week of pregnancy at the hospital antenatal clinic. Previous pregnancies were uneventful and there was no record of serious illnesses. The family history was irrelevant.

The present preznancy progressed uneventfully until early in the sixth month when she had a severe haemorrhage from a varicose ulcer of the leg. On her first visit to the antenatal clinic on January 15 , 1951, she complained of breathlessness, frequency of micturition, and suprapubic pain. On examination she was seen to be of fair nutrition but the skin and mucous membranes were very pale. There was no evidence of icteric pigmentation, koilonychia, glossitis, or of splenic or lymphatic glandular enlargement. No toxaemic manifestations and no abnormalities of heart or lungs were noted. The Wassermann reaction was negative and her blood group was $\mathrm{A}, \mathrm{Rh}$ negative (no antibodies with anti-D serum). Blood levels were: Hb 7.6 g. \%, red blood cells $3.95 \times 10^{6} /$ c.mm., colour index 0.69. Examination of a catheter specimen of urine showed oxalate crystals, a few clumps of pus cells, and coliform organisms on culture. She was given a course of sulphamerazine and alkalis pending admission to the obstetrical ward.

After admission on February 2 repeated examination revealed a persistent pyuria ; $30 \mathrm{~g}$. of sulphamerazine, $10.5 \mathrm{~g}$. of chloromycetin, and a subsequent course of sulphatriad were given before the urine became sterile. During the administration of these antibiotics a course of "ferrivenin "was given, in all containing 1,500 mg. of elemental iron. Despite this, the blood values continued to fall.

Two weeks after admission she developed symptoms of an upper respiratory infection, with herpes of the lips, and two episodes of epistaxis. To improve her condition before delivery, she was given two pints of whole blood which raised the $\mathrm{Hb}$ to $10.0 \mathrm{~g} . \%$ and red blood cells to $3.75 \times 10^{6} / \mathrm{c} . \mathrm{mm}$. Surgical induction was now performed and she was delivered of a healthy girl on February 28 after a labour of seven hours five minutes. Blood loss was minimal. A low-grade intermittent pyrexia persisted until the seventeenth day of the puerperium despite continuous penicillin therapy.

On March 3, after transfer to a medical ward, the $\mathrm{Hb}$ had fallen to $4.6 \mathrm{~g} . \%$ and the red blood cells to $1.9 \times 10^{6} / \mathrm{c} . \mathrm{mm}$. A white-cell count on March 6 gave 5,400 c.mm. (Table I); platelets. $75,000 /$ c.mm. Peripheral blood films showed moderate polychromasia, marked hypochromia and anisocytosis, a small proportion of macrocytes, extremely scanty platelets, and a few immature white cells. The coagulation time was normal but the bleeding time was prolonged (12 minutes by Duke's method). Sternal marrow examination revealed the presence of megaloblastic erythropoiesis. The serum bilirubin level was $0.4 \mathrm{mg} . \%$. The urinary urobilinogen was excessive. Free hydrochloric acid was present in the gastric contents. Tests for faecal occult blood were negative, and a barium meal and radiograph of the chest were also negative.

Folic-acid therapy, $20 \mathrm{mg}$. daily, was begun on March 10, as well as two "complevite" tablets three times daily, the latter providing 3 grains ferrous sulphate daily. Within the next 48 hours there was a remarkable outpouring of immature white cells into the peripheral blood (Fig. 1 and Table I), the picture simulating that found in myelogenous leukaemia. These findings persisted for five days only. However. by the sixth day the spleen had become palpable three fingerbreadths below the costal margin although the patient now showed obvious clinical improvement and this had been accompanied by a reticulocyte response of $14 \%$ on the fifth day of treatment. The spleen remained palpable for four weeks. Six weeks after the beginning of folic-acid therapy the marrow showed a normal white-cell picture and erythropoiesis 


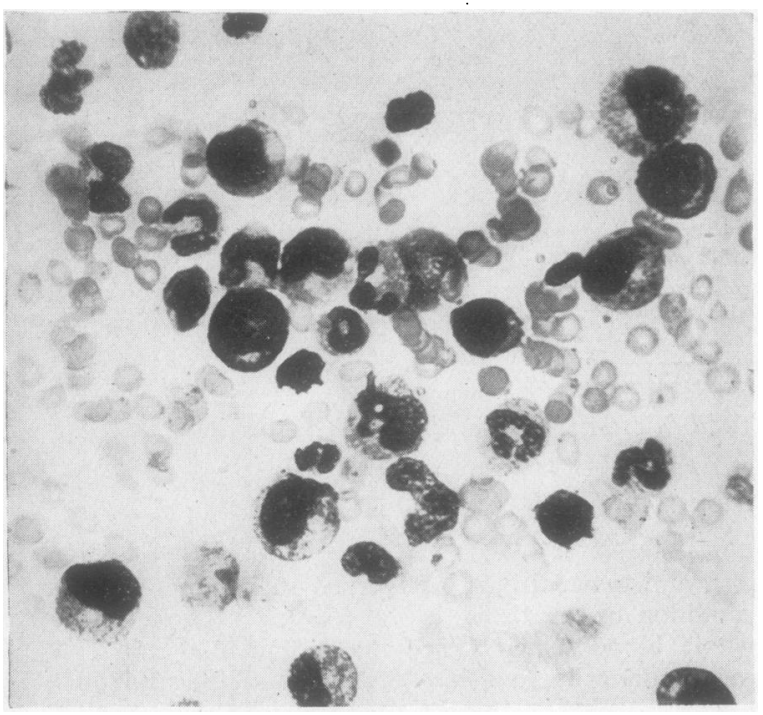

Fig. 1.-Peripheral blood at the height of the leukaemoid phase showing early forms of white cells, $\times 500$.

TABLE I

TOTAL WHITE CELL AND DIFFERENTIAL COUNTS ON PERTINENT DATES

\begin{tabular}{|c|c|c|c|c|c|c|}
\hline Date & $6 / 3 / 51$ & $12 / 3 / 51$ & $13 / 3 / 51$ & $14 / 3 / 51$ & $16 / 3 / 51$ & $31 / 5 / 51$ \\
\hline Total/c.mm. & 5,400 & 42,000 & 21,000 & 18,400 & 12,000 & 4,500 \\
\hline Polymorphonu - & 45 & $40 \cdot 5$ & 41.0 & 41.0 & $37 \cdot 0$ & 51.0 \\
\hline $\begin{array}{l}\text { Mo }(\%) \\
\text { Myelocytes }(\%) \\
\text { Premyelocytes }(\%) \\
\text { Blast cells }(\%) \\
\text { Monocytes }(\%) \\
\text { Lymphocytes }(\%) \\
\text { Macropoly }\end{array}$ & $\begin{array}{r}4 \\
1 \\
1 \\
1 \\
9 \\
34\end{array}$ & $\begin{array}{r}7 \cdot 5 \\
10 \cdot 0 \\
4 \cdot 0 \\
1 \cdot 5 \\
7 \cdot 0 \\
9 \cdot 5\end{array}$ & $\begin{array}{r}8 \cdot 0 \\
5 \cdot 0 \\
7 \cdot 0 \\
1 \cdot 0 \\
7 \cdot 0 \\
15 \cdot 0\end{array}$ & $\begin{array}{r}13 \cdot 0 \\
5 \cdot 0 \\
4 \cdot 0 \\
0 \cdot 5 \\
7 \cdot 5 \\
16 \cdot 0\end{array}$ & $\begin{array}{r}9 \cdot 0 \\
1 \cdot 0 \\
2 \cdot 0 \\
1 \cdot 0 \\
7 \cdot 0 \\
30 \cdot 0\end{array}$ & $\begin{array}{l}4 \cdot 0 \\
= \\
8 \cdot 0 \\
37 \cdot 0\end{array}$ \\
\hline $\begin{array}{l}\text { Macropolycytes } \\
\text { Normoblasts }(\%) \\
\text { Megaloblasts (\%) } \\
\text { Unclassified (\%).. }\end{array}$ & $\begin{array}{l}2 \\
1 \\
2 \\
-\end{array}$ & $\begin{array}{r}2 \cdot 5 \\
11 \cdot 0 \\
4 \cdot 5 \\
2 \cdot 0\end{array}$ & $\begin{array}{r}10 \cdot 0 \\
4 \cdot 0 \\
2 \cdot 0\end{array}$ & $\begin{array}{r}0 \cdot 5 \\
10 \cdot 5 \\
2 \cdot 0 \\
-\end{array}$ & $\begin{array}{r}1 \cdot 0 \\
10 \cdot 0 \\
2 \cdot 0\end{array}$ & = \\
\hline
\end{tabular}

was normoblastic. This was again confirmed after a further period of six weeks.

Final blood values before discharge on April 24 were $\mathrm{Hb} 12.1 \mathrm{~g} . \%$, red blood cells $4.5 \times 10^{6} / \mathrm{c} . \mathrm{mm}$., and white blood cells $6,800 /$ c.mm. (normal differential). No further haematinics have been given and the patient has remained extremely well. Periodic examination to date has shown a completely normal blood picture.

\section{Discussion}

Over the past century a large volume of literature has accumulated on the subject of severe anaemias of pregnancy. Most interest, however, has been focused on dyserythropoiesis and relatively little attention has been paid to white-cell abnormalities.
In the so-called pernicious anaemia of pregnancy there may be considerable variation in the state of the white cells. A few published reports mention the occurrence of immature white cells in the peripheral blood (Evans, 1929 ; Callender, 1944 ; Moore, Bierbaum, Welch, and Wright, 1945 ; Wintrobe, 1946). In 1946 Foy, Kondi, and Murray described a case presenting as a macrocytic anaemia, with megaloblastic marrow and free acid in the gastric juice after histamine. In the later stages of the disease the blood became "leukaemic" with 30,000 to 189,000 white blood cells per c.mm., $80-90 \%$ of which were myeloblasts. They classified their case as an example of "leukanaemia." In 1948 Gillespie and Ramsay reported a case of pernicious anaemia of pregnancy in which there was such an extreme degree of white cell immaturity as to raise the question of leukaemia ; necropsy revealed caseous tuberculosis of the hilar glands and lungs. This association of tuberculosis and a leukaemoid blood picture has already been noted (Custer and Crocker, 1932 ; Leibowitz, 1938).

It is well known that in megaloblastic anaemias with leucopenia, either liver, vitamin $B_{12}$, or folico acid are able to produce a rise of white cells intog the normal range. However, only in the cases reported by Foy, Kondi, and Murray and by? Gillespie and Ramsay has the extent and character of the white-cell response suggested the possibility of leukaemia.

A leukaemoid picture may occur in response to severe infections, including tuberculosis, and also in malignant tumours (Meyer and Rotter, 1942). Of the drugs used in the present case, penicillin alone merits consideration. A case of megaloblastic anaemia has recently been reported by Foy, Kondi, and Hargreaves (1951), in which treatment by penicillin $G$ alone induced a response in no way different from that obtained by potent liver extracts, folic acid, etc. In the present case, however, no improvement in the anaemia and no leucocytosis occurred while penicillin alone was used.

Reference has already been made to the undoubted effect of folic acid on the granular series, and in this case it seems most probable that its effectiveness was enhanced by its administration at a time when a partial spontaneous remission was occurring and when conditions were most favourable for regeneration of all marrow elements It would, therefore, appear that the case described above presents an exceptionally marked example of the white-cell response which might normally have been expected to occur. 


\section{Summary}

A case of megaloblastic anaemia of pregnancy, presenting an extensive myeloid response during the course of folic acid therapy, is reported.

The author wishes to express her gratitude to Dr. James McIntosh for permission to publish this case and for much helpful guidance, to Dr. D. McKay Hart for the obstetrical records, and to Mr. Percy Boot for the photomicrograph.

\section{REFERENCES}

Callender, S. T. E. (1944). Ouart. J. Med., 13, 75.

Custer, R. P., and Crocker, W. J. (1932). Folia haemat., Lpz., 46, 359.

Evans, W. (1929). Lancet, 1, 14.

Foy, H., Kondi, A., and Hargreaves, A. (1951). Brit. med. J., 1, 380. Murray (1946). J. Path. Bact., 58, 157.

Gillespie, M., and Ramsay, A. M. (1948). Brit. med. J., 1, 828.

Leibowitz, S. (1938). Arch. Path., Chicago, 25, 365.

Meyer, L. M., and Rotter, S. D. (1942). Amer. J. clin. Path., 12, 218

Moore, C. V., Bierbaum, O. S., We'ch, A. D., and Wright, L. D (1945). J. Lab. clin. Med., 30, 1056

Wintrobe, M. M. (1946). Clinical Hematology, 2nd ed., p. 365 London. 